\title{
Characteristics of chemical eye injuries
}

\section{Katarkteristike hemijske povrede oka}

\author{
Marija Matovic, Katarina Janicijevic, Mirjana A. Janicijevic \\ Petrovic \\ Department of Medical Support , The Gendarmerie , Kraljevo, Serbia \\ RECEIVED 13.11.2015. \\ ACCEPTED 11.01.2016.
}

\section{ABSTRACT}

Introduction: Chemical eye injuries are described as trauma of the eye, which represent an urgent state in ophthalmology, and are mostly localized, on the anterior segment. Causes of injuries are acid, alkali, mixed and non identified agents. Diagnostic procedures are easy, but therapy is complex.

Aim: to describe the historical characteristics of chemical eye trauma and analyze the causes as the most common agents involved in chemical injuries at tertiary level of referent region.

Material and Methods: The retrospective study conducted on data of the chemical eye injuries presented at Clinic of ophthalmology in Clinical Centre of Kragujevac (Central Serbia) in past three years. One hundred and thirteen patients (164 eyes) who were presented from September, 2013 to September, 2015 for observation with chemical eye injuries were included in this study. Authors analyzed and showed the most important of historical characteristics: gender, age, categories of chemical agents and location of the accident.

Results: Males were more often reported with injures than females $(66.37 \%$ vs. $33.63 \%)$. The mean age across categories was $46-60$ years $(54,47.79 \%)$. The most common categories of chemical agents: hydrochloric acid - 42 eyes (25.61\%), acetic acid -37 eyes (22.56\%), quicklime - 37 eyes $(22.56 \%)$, quenched - 24 eyes (14.63\%) and mixed - 24 eyes (14.63\%). The location where injury occurred was mostly at home -84 eyes $(51.22 \%)$ and at work - 80 eyes $(48.78 \%)$.

Conclusion: Correlation of references from this study and world references in the medium urban countries with dominators light industries was developed to be relatively identical. In frequency from this study allocated by chemical eye injury males dominated professionally in social and private industry sector while female in households while maintaining general hygiene dominated it. Frequently bases were quenched and quicklime. The most common location was inside the home.

Keywords: history characteristics, chemical eye injuries, categories of agent, urban countries, location of injuries

\author{
Marija Matović, Katarina Janicijevic, Mirjana A. Janićijević \\ Petrović \\ Odsek za sanitetsko obezbeđenje, Odred žandarmerije, Kraljevo \\ PRIMLJEN 13.11.2015. \\ PRIHVAĆEN 11.01.2016.
}

\section{SAŽETAK}

Uvod: Hemijske povrede oka su opisane kao traume, koje predstavljaju hitno stanje u oftalmologiji i uglavnom su lokalizovane na prednjem segmentu oka. Uzroci povreda su kiseline, baze, mešoviti i neidentifikovani agensi. Dijagnostički postupci su laki, ali je terapija složena.

Cilj - opisivanje anamnestičkih karakteristika hemijskih povreda oka i analiza najčešćih uzroka hemijskih povreda na nivou tercijarne zaštite, referentnog regiona.

Materijal/Metode: Retrospektivna studija obuhvatila je hemijske povrede oka, koje su observirane na Klinici za oftalmologiju, Kliničkog centra u Kragujevcu (Centralna Srbija) u poslednje tri godine. Stotinu i trinaest pacijenata, odnosno 164 očiju, je observirano od septembra 2013. do septembra 2015. godine. Autori su analizirali i pokazali najvažnije anamnestičke karakteristike: pol, starost, vrste hemijskih agenasa i lokacije gde su se desile hemijske povrede oka.

Rezultati: Muškarci su se češće povređivali hemijskim agensima nego žene - 66,37\% prema 33,63\%. Najčešća starost po dobnim kategorijama je bila $46-60$ godina (54, $47,79 \%)$. Najčešći hemijski agenasi su bili: hlorovodonična kiselina - 42 oka $(25,61 \%)$, sirćetna kiselina - 37 očiju $(22,56 \%)$, kreč - 37 očiju (22,56\%), negašeni kreč - 24 oka $(14,63 \%)$ i mešovite materije - 24 oka (14,63\%). Lokacija gde je došlo do povrede je bila uglavnom kod kuće - 84 očiju $(51,22 \%)$ i na radnom mestu - 80 očiju $(48,78 \%)$.

Zaključak: Korelacija podataka ove studije i svetskih referenci, a u srednje razvijenim zemljama sa dominacijom lake industrije, u domenu hemijskih povreda oka je do identična. Najčešće hemijske povrede oka u ovoj studiji, a kod muškaraca su dominirale u industrijskom, društvenom i privatnom sektoru, vezano za profesije, dok je dominacija hemijskih povreda kod žena bila u domaćinstvima, priliom održavanja opšte higijene. Najčešći agensi su bile baze, odnosno kreč i negašeni kreč. Najčešća lokacija je bila u domaćinstvima.

Ključne reči: anamnestičke karakteristike, hemijske povrede oka, vrste agenasa, urbana sredina, lokacija povreda 


\section{INTRODUCTION}

Chemical eye injuries fall into urgent ophthalmological pathology and are usually localized on anterior segment with clinical complications and residual sequels as macular corneal opacities, neovascularization, dry eye, secondary glaucoma, etc. ${ }^{1,2}$

The most common causes of chemical eye injuries were acids, bases, mixed and unidentified substances. Chemical burns by strong acids or bases are responsible for the most serious injuries and blindness. ${ }^{3,4}$

Chemical agents sustained serious injury to the eyes, head and neck area, all of which required urgent medical therapy and surgical intervention. The chemical eye injuries occur in setting of accidents at workplace or at home, at agriculture, in traffic, or during the physical attacks. Diagnostic procedures are easy, but therapy is complex.-8

\section{MATERIAL AND METHODS}

The retrospective study conducted on data of chemical eye injuries presented at Clinic of ophthalmology in Clinical Centre Kragujevac (Central Serbia) in past three years graded in three clinical stadiums, clinical grade I-III.

One hundred and thirteen patients (164 eyes) presented in our Eye department (referent tertiary region) between September, 2013 to September, 2015 for observation and medical treatment of the chemical eye injuries.

Authors have analyzed and showed the most important of the historical characteristics: gender, age, the most common categories of chemical agents (nature of chemical agent) and the location - place where injury occurred.

Approval of the relevant Ethics Committee was obtained. The statistical analysis was performed in SPSS program, version 20.00 (Chi-Squire test, $\mathrm{p}<0.005$ ).

\section{RESULTS}

Males were more often reported with injures than females $75: 38$ (66.37\% vs. $33.63 \%)$, to $2: 1$ of all patients (113) with statistical significant $\left(\chi^{2}=12.115, \mathrm{p}=0.001\right)$.

The most frequent age group across all categories were $46-60$ years - $54(47.79 \%)$ with statistical significant $\left(\chi^{2}=37.690, p=0.000\right)$, table 1 . The most common categories of chemical agents were hydrochloric acid - 42 (25.61\%), acetic acid - 37 (22.56\%), quicklime - 37 (22.56\%), quenched $-24(14.63 \%)$ and mixed $-24(14.63 \%)$ of all eyes (164), which is not statistically significant $\left(\chi^{2}=3.947\right.$, $\mathrm{p}=0.413$ ), table 1 . Ten cases (unilateral) of all observed were defined as no identified chemical agents (6.1\% of all eyes), those authors did not include in statistical investigation. The location where injury occurred was mostly at home - 84 $(51.22 \%$ eyes) and at work place $-80(48.78 \%$ eyes $)$, which was not statistically significant $\left(\chi^{2}=0.221, p=0.638\right)$. (Table 1)

Table 1. Historical characteristics of the chemical eye injuries

\begin{tabular}{|c|c|c|c|c|c|c|c|c|c|c|c|c|c|c|c|}
\hline \multirow{3}{*}{ Year } & \multicolumn{13}{|c|}{ CHEMICAL EYE INJURIES } & \multirow{3}{*}{ Patient } & \multirow{3}{*}{ Eye } \\
\hline & \multicolumn{2}{|r|}{ Sex } & \multicolumn{4}{|c|}{ Age (years) } & \multicolumn{5}{|c|}{ Chemical agent } & \multicolumn{2}{|c|}{ Place } & & \\
\hline & male & female & $15-30$ & $31-45$ & $46-60$ & $>60$ & $\begin{array}{l}\text { chloral } \\
\text { acid }\end{array}$ & $\begin{array}{l}\text { acetic } \\
\text { acid }\end{array}$ & $\begin{array}{l}\text { quick- } \\
\text { lime }\end{array}$ & $\begin{array}{l}\text { quen- } \\
\text { ched }\end{array}$ & mix. & home & work & & \\
\hline 2013 & 17 & 10 & 3 & 6 & 14 & 4 & 11 & 10 & 8 & 6 & 5 & 20 & 20 & $\begin{array}{c}27 \\
23.89 \\
\%\end{array}$ & 40 \\
\hline 2014 & 28 & 13 & 3 & 10 & 21 & 7 & 17 & 13 & 12 & 10 & 7 & 28 & 31 & $\begin{array}{c}41 \\
36.28 \\
\% \\
\end{array}$ & 59 \\
\hline 2015 & 30 & 15 & 4 & 13 & 19 & 9 & 14 & 14 & 17 & 8 & 12 & 36 & 29 & $\begin{array}{c}45 \\
39.82 \\
\%\end{array}$ & 65 \\
\hline \multirow[b]{2}{*}{$\Sigma 3$} & $\begin{array}{c}75 \\
66.37 \\
\%\end{array}$ & $\begin{array}{c}38 \\
33.63 \\
\%\end{array}$ & $\begin{array}{c}10 \\
8.85 \\
\%\end{array}$ & $\begin{array}{c}29 \\
25.66 \\
\%\end{array}$ & $\begin{array}{c}54 \\
47.79 \\
\%\end{array}$ & $\begin{array}{c}20 \\
7.7 \%\end{array}$ & $\begin{array}{c}42 \\
25.61 \\
\%\end{array}$ & $\begin{array}{c}37 \\
22.56 \\
\%\end{array}$ & $\begin{array}{c}37 \\
22.56 \\
\%\end{array}$ & $\begin{array}{c}24 \\
14.63 \\
\%\end{array}$ & $\begin{array}{c}24 \\
14.63 \\
\%\end{array}$ & $\begin{array}{c}84 \\
51.22 \\
\%\end{array}$ & $\begin{array}{c}80 \\
48.78 \\
\%\end{array}$ & \multirow[b]{2}{*}{113} & \multirow[b]{2}{*}{164} \\
\hline & \multicolumn{2}{|c|}{113} & \multicolumn{4}{|c|}{113} & \multicolumn{5}{|c|}{113} & \multicolumn{2}{|c|}{164} & & \\
\hline
\end{tabular}

Monocular chemical injuries dominated in relation to bilateral in our patients, as about 1.5:1, table 1 .

Analysis of chemical injuries by year of observation points to the continuing growth of the same, which was in 2013 there were 27 patients ( 40 eyes), in 2014 - 41 patients (59 eyes) and in 2015 - 45 patients (65 eyes), table 1. 
People in middle age are more likely to violate compared to younger and older adults. Middle-aged men are more frequently injured than the middle-aged women $\left(\chi^{2}=4.299\right.$, $\mathrm{p}=0.231)$ which is not statistically significant, that in this study, both violate both sexes middle age.

Correlation between gender and the nature of chemical agents $\left(\chi^{2}=1.407, \mathrm{p}=0.843\right)$ indicates no statistical significance, and most chemical agents did not show dominance by gender. Correlation between gender and place of injury was statistically significant $\left(\chi^{2}=1.407, p=0.843\right)$ which indicates that men were more frequently injured on the job, in government or private sector, and women were performing house activities.

Correlation of age with the nature of chemical agents $\left(\chi^{2}=5.044, \mathrm{p}=0.956\right)$ which was not statistically significant, showing that they did not stand dominant chemical agent population by age, among the subjects of this study.

Correlation between age and place of injury $\left(\chi^{2}=12.139\right.$, $\mathrm{p}=0.007)$ which was statistically significant, showing that population of younger and older age groups are more frequently injured on the job, and older adults more often when performing tasks at the home.

Correlation common nature chemical agents, permanent injury $\left(\chi^{2}=1.921, p=0.750\right)$ which was not statistically significant difference, showing that there was no dominant, chemical agents in relation to the place of injury in our study.

\section{DISCUSSION}

The estimated prevalence rate in the Central region of Serbia (Kragujevac) of severe ocular chemical injury was 1.68 per 100000 patients. Our region is not in domain of heavy industry, but is dominated by lighter, chemical industries, foods, and for that reason, dominated by chemical injury, more common in men, in the ratio of 2:1 compared to women.

Commonly substances are distinguished: acid in household (personal hygiene); bases in whitewashing of homes (buildings); from the car battery mix - acid (traffic); mixed or as no identified chemical agents (physical attacks).The most common categories of chemical agents were cleaning and whitewashing agents, personal care products and the automotive chemicals.

Place of the injury was home (private professional services, sports activities, hobbies) and jobs (car industry "Fiat" and social sectors of the prepare foods, as bread, milk, meat, cooks). The continuous increase in chemical eye injuries reasoning suggests that development of additional light, chemical, manufacturing our reference areas, as well as the fast pace of work and life and with an increased the risk factor - stress.

The most common causes of injury were work-related (49.0\%) and chance events (42.0\%). The most frequent ocular injury was globe injury (95.6\%), including mechanical (77.6\% - closed trauma of the eye and 5.9\% - open trauma of the eye), chemical injuries (7.6\%), photo injuries (2.3\%) and thermal injuries $(2.2 \%)$, as similar chemical injuries in this study and the study of ocular traumatic injuries in Iran. ${ }^{1}$

Ocular or thermal burns account for $7.7 \%$ to $18 \%$ of ocular trauma. In order to decrease the incidence of the burn, and the prevention particularly in industry is essential, as similar in our country. ${ }^{2}$

The prevalence of severe ocular chemical injury in Shanghai was low. Successful management provides good prognosis for most patients and the complications were found in $93 \%$, whose opinions authors also share based on the results from this study. ${ }^{3}$ Information collected via medical record review classifying chemical agents in obvious categories based on the patient's report of intended use of the product. The demographic measures and work-related status were described overall and by chemical agent category, what congruous with authors evaluation as well. ${ }^{4}$

Various ocular alkaline burn classification schemes are mostly used to grade human chemical eye injuries in purpose of identifying treatments and forecasting outcomes. Information will have clinical application, as well as use in development and validation of new methods to assess ocular toxicity. ${ }^{5}$

Midelfart at al., analyzing concluded that the men were involved about twice as frequently as women, and most of them were obtained at work. The majority of women obtained their injuries at home. Alkalis were the most frequent chemical, implicated in $48 \%$ cases, while strong acid caused $20 \%$ of injuries, similar results were obtained in cases of this study. ${ }^{6}$

Chemical assaults in Hong Kong described that many victims sustained the burn injury to the head and neck area ( $47 \%$ of victims' eyes were burnt). A total of $84 \%$ required surgical intervention, but cases included in this study were clinically different and did not require any surgical intervention.?

In most cases, chemical eye injuries were not sight threatening. Improvements in product labeling and design could represent an avenue in prevention of different chemical eye trauma. Unexpected number of chemical injury in age over 60 years, with men or women, was by personal hygiene or cosmetics, as well as for example cologne water, easy for drier, with remedies and glue, etc. The violations of spray with mixed chemical substances on the other hand are 
expected in younger people. Frequently acids were hydrochloric acid in hygiene home, acetic acid - canning and food preparation and mixture of battery acid in the automotive works. The most frequent bases were quenched and quicklime (whitewashing walls). Unidentified substances were related mainly to intentional chemical injuries with various agents in the relation of the human conditions. ${ }^{8,9}$

\section{CONCLUSION}

Correlation of our and world references (historical characteristics of chemical eye injuries) in medium urban countries, as this study was conducted, with dominators medium and light industries developed was relatively identical, except that in frequency from our study allocated by chemical injury of males professionally in social and private sector.

Frequency in this study dominated by female was in households, while maintaining general hygiene and at cooks. Frequently bases were quenched and quicklime (whitewashing walls). Frequently location was in the homework.

\section{REFERENCES}

1. Jafari AK, Anvari F, Ameri A, Bozorgui S, Shahverdi N. Epidemiology and socio demographic aspects of ocular traumatic injuries in Iran. Int Ophthalmol 2010; 30(6): 691-6.

2. Merle H, Gérard $M$, Schrage N. Ocular burns. J Fr Ophtalmol 2008; 31(7): 723-34.

3. Hong J, Qiu T, Wei A, Sun X, Xu J. Clinical characteristics and visual outcome of severe ocular chemical injuries in Shanghai. Ophthalmology 2010; 117(12): 2268-72.

4. Blackburn J, Levitan EB, MacLennan PA, Owsley C, McGwin G Jr. The epidemiology of chemical eye injuries. Curr Eye Res 2012; 37(9): 787-93.

5. Bagley DM, Casterton PL, Dressler WE, Edelhauser HF, Kruszewski FH, McCulley JP, Nussenblatt RB, Osborne R, Rothenstein A, Stitzel KA, Thomas K, Ward SL. Proposed new classification scheme for chemical injury to the human eye. Regul Toxicol Pharmacol 2006; 45(2): 206-13.

6. Midelfart A, Hagen YC, Myhre GB. Chemical burns to the eye. Tidsskr Nor Laegeforen 2004; 124(1): 49-51.

7. Young RC, Ho WS, Ying SY, Burd A. Chemical assaults in Hong Kong: a 10-year review. Burns 2002; 28(7): 651-3.

8. Blackburn J, Levitan EB, MacLennan PA, Owsley C, McGwin G Jr. The epidemiology of chemical eye injuries. Curr Eye Res 2012; 37(9): 787-93.

9. Gicquel JJ. Management of ocular surface chemical burns. Br J Ophthalmol 2011; 95(2): 159-61. 